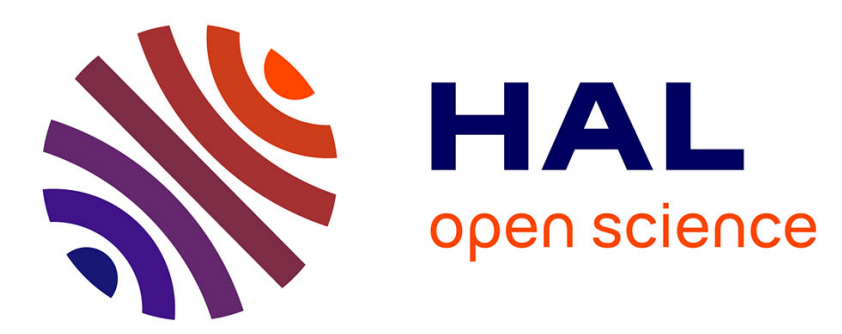

\title{
Cathodic carboxylation of gold in thick Au-CO2n layers. A model for reversible electrochemical sequestration of $\mathrm{CO} 2$
}

\author{
Viatcheslav Jouikov, Jacques Simonet
}

\section{- To cite this version:}

Viatcheslav Jouikov, Jacques Simonet. Cathodic carboxylation of gold in thick Au-CO2n layers. A model for reversible electrochemical sequestration of CO2. Electrochemistry Communications, 2015, 59, pp.40-42. 10.1016/j.elecom.2015.06.020 . hal-01188187

HAL Id: hal-01188187

https://hal-univ-rennes1.archives-ouvertes.fr/hal-01188187

Submitted on 25 Nov 2015

HAL is a multi-disciplinary open access archive for the deposit and dissemination of scientific research documents, whether they are published or not. The documents may come from teaching and research institutions in France or abroad, or from public or private research centers.
L'archive ouverte pluridisciplinaire HAL, est destinée au dépôt et à la diffusion de documents scientifiques de niveau recherche, publiés ou non, émanant des établissements d'enseignement et de recherche français ou étrangers, des laboratoires publics ou privés. 


\title{
Cathodic Carboxylation of Gold in Thick $\left\{\mathrm{Au}-\mathrm{CO}_{2}\right\}_{n}$ Layers.
}

\section{A Model for Reversible Electrochemical Sequestration of $\mathrm{CO}_{2}$.}

\author{
Viatcheslav Jouikov $^{\mathrm{a}}$ and Jacques Simonet ${ }^{\mathrm{b}}$ * \\ a) UMR 6226, CPM, Université de Rennes 1, Campus de Beaulieu, 35042 Rennes Cedex, France \\ b) Laboratoire MaSCE, UMR 6226, Université de Rennes 1, Campus de Beaulieu, 35042 Rennes \\ Cedex, France.
}

\begin{abstract}
Catalytic reduction of $\mathrm{CO}_{2}$ (saturated in organic polar solvents, e.g. N,N-dimethylfomamide, containing $\mathrm{Me}_{4} \mathrm{NX}$ or $\mathrm{NaBF}_{4}$ ) was achieved at smooth gold electrodes and at glassy carbon electrodes galvanostatically capped with a thin layer of gold. Under these quite explicit conditions, very sharp reduction steps were observed near $-1.5 \mathrm{~V}$ vs. $\mathrm{Ag} / \mathrm{AgCl}$. With small cations listed above, an unexpected behaviour was observed, a progressive electrode inhibition occurring upon several scans or after a fixed-potential electrolysis at $\mathrm{E}<-1.7 \mathrm{~V}$. This phenomenon could be attributed to the insertion of $\mathrm{CO}_{2}$ into gold, leading to the formation of a thick iono-metallic multi-strata layer (less conducting than pure metal) that grows with the electrode charge. The formation of this new interface is due to the concur of three elements: transient $\mathrm{CO}_{2}$ anion radical, the metal, and rather small-sized cations $\left(\mathrm{M}^{+}=\right.$ $\mathrm{Na}^{+}$or $\mathrm{TMA}^{+}$), the three possibly associated in a form $\left\{\mathrm{Au}-\mathrm{CO}_{2}{ }^{-}, \mathrm{M}^{+}\right\}$apparently very reactive with oxygen, moisture, and with some organic $\pi$-acceptors. Upon multi-scans up to $-2.2 \mathrm{~V}$, the thickness of formed layer progressively increases reaching more than $10^{-7}$ to $10^{-6} \mathrm{~mol} \mathrm{~cm}$ ${ }^{2}$. Such multi-layers undergo decomposition in the anodic domain at about $+1.7 \mathrm{~V}$ liberating $\mathrm{CO}_{2}$ beforehand trapped in Au. Coulometric analyses demonstrated that insertion (cathodic) and release (anodic) steps are quite equivalent, which permits to consider this process as chemically reversible sequestration of carbon dioxide.
\end{abstract}

Keywords: Gold electrodes; modified electrodes; carboxylation of conducting solids; Au$\mathrm{CO}_{2}$ grafting; fixation of $\mathrm{CO}_{2}$

\section{Corresponding author:}

Jacques Simonet,

Tel: +33 (0) 2232362 92, jacques.simonet@univ-rennes1.fr

\section{Introduction}

Electrochemistry is a valuable technique for the insertion of free organic radicals and ions into carbon and metallic matrixes. Alternatively, it is also an interesting way for generating new interfaces, allowing the building of new catalytic electrodes. Among the possibilities for transforming the structure of conductive materials (in particular, carbons and different 
graphites using electrogenerated organic radicals [1]), the reactivity of gold with free radicals [2], that of mercury via tetraalkylammonium $\left(\mathrm{TAA}^{+}\right.$) amalgams [3], and also the unexpected insertion of salts or cations into platinum and palladium within the cathodic range [4] permit to think that all these cases have the same general phenomenon in common, which is worth to be carefully considered for electrochemistry in the future. Thus, cathodic reactivity of TAA ${ }^{+}$ cations with post-transition metals (antimony, tin, lead) remains of high interest [5]. Generally, such reactions lead to the formation of new materials, possessing reducing abilities as electron transfer agents [6], and should be carried out under inert atmosphere.

On the other hand, catalytic capacities of gold were considerably developed in organic chemistry [7] but much less in electrochemistry: for some reasons, platinum is preferred in analytical electrochemistry, possibly because of its long use. So far, gold essentially remains an excellent tool for fixing thiolates [8]. However, reduction of aryl-diazonium salts on gold results in primary immobilized layer that could further be functionalized via click chemistry permitting attachment of organic groups onto Au NPs $[9,10]$.

Small-size electroactive molecules could-after electron transfer at a metallic interfaceact as vectors penetrating and diffusing into metals. The nature of metal and ion-pairs formed with the counter-ion of supporting electrolyte should be considered here. We might expect that carbon dioxide is scheming in this context because its apparent reduction potential is very dependant on the electrode material and on the supporting electrolyte; it certainly obeys catalytic rules already observed with many solid conducting materials such as glassy carbon [11], graphite [12], graphene [13], and lead [14,15].

With this in mind, gold is now used as a catalytic material for the reduction of $\mathrm{CO}_{2}$ in the presence of $\mathrm{Na}^{+}$and of some $\mathrm{TAA}^{+}$salts in polar aprotic solvents. It is presented here a very simple scheme where the reduced form of $\mathrm{CO}_{2}$ (presumably, its anion radical) may induce-under very specific conditions-a paired formation-insertion of an ion/gold intermediate leading to a drastic drop of conductivity of the electrode.

This process is interestingly related to a coupled anodic step (equivalent in terms of charge to the cathodic step) which is attributed to the release of also permit their carboxylation (superficial and massive). Thus, the process described here could be considered as a reversible sequestration of $\mathrm{CO}_{2}$ and be seen as a model for the carboxylation of a wide series of non-corrodible metals (from palladium to rhodium).

\section{Experimental section}

\subsection{Salts and solvents}


In the present work, essentially $0.1 \mathrm{M}$ solutions of tetramethylammonium and sodium tetrafluoroborates in dimethylformamide (DMF) were used. Salts and solvents were purchased from Aldrich (quality for syntheses). The procedures given hereafter can be performed even in reasonably dry commercial solvents, used as received (water content $>800$ ppm). For excluding oxygen, all electrochemical experiments were performed under inert atmosphere bubbling argon through the solution. Alternatively, corresponding to the aim of this study, liquid electrolytes were saturated with $\mathrm{CO}_{2}$ (from Air Liquide) bubbling it for 5 min at room temperature.

All potentials are referred to aqueous $\mathrm{Ag} / \mathrm{AgCl} / \mathrm{KCl}_{\text {sat }}$ electrode. The electrochemical instrumentation has been previously described $[11,12]$.

\subsection{Working electrodes}

Gold and glassy carbon (GC) electrodes used for voltammetry had an apparent surface area of $0.8 \mathrm{~mm}^{2}$. Before using, their surfaces were carefully polished with silicon carbide paper (Struers 500 and 1200) or with Norton polishing paper (type 02 and 03) and rinsed with water, alcohol and at last with acetone. After recurrent scans or fixed potential electrolyses, gold electrodes were eventually sonicated for two minutes. Finally, the electrodes were dried with a hot air flow for $30 \mathrm{~s}$. Coulometry and electrolyses reported in this work were carried out using three-electrode two-compartment cells with a total catholyte volume of about $5 \mathrm{~mL}$.

\subsection{Organic materials}

All organic compounds used for testing gold materials, modified by insertion of $\mathrm{CO}_{2}$, were purchased from Merck and Aldrich.

\section{Results}

\subsection{Reactivity of $\mathrm{CO}_{2}$ at a negatively polarized gold electrode.}

Obviously, the experiments described hereafter might appear to a general reader as quite unusual. When polarized gold $(\mathrm{E}<-1.5 \mathrm{~V})$ and carbon dioxide meet under specific conditions (in the presence of small-sized cations of supporting electrolyte), a spectacularly sharp reduction peak is observed (Figure 1), in contrast to the usual reduction step obtained when using large-sized $\mathrm{Bu}_{4} \mathrm{~N}^{+}$cations (Figure 1, A), and which stems from a strongly inhibiting process certainly due to the formation of an organometallic species at gold interface. More specifically, as is featured in Scheme 1, the electrochemical technique may provide a very 
easy way to form an intermediate, allying $\mathrm{Au}$ and $\mathrm{CO}_{2}$ (tentatively written as $\left\{\mathrm{Ag}-\mathrm{CO}_{2}{ }^{-}, \mathrm{M}^{+}\right\}$ with $\mathrm{M}^{+}$representing the cation of the electrolyte). In these experiments, we essentially used the solutions of $\left(\mathrm{TMA}^{+} \mathrm{BF}_{4}{ }^{-}\right)$in $\mathrm{DMF}$ saturated with $\mathrm{CO}_{2}$ (to $0.2 \mathrm{~mol} \mathrm{~L}{ }^{-1}$ at $\mathrm{RT}[16,17]$ ), in contact with the polarized smooth gold electrode. Linear voltammetry reveals a strong increase of intensity at $\mathrm{E} \leq-1.4 \mathrm{~V}$ (sharp peak (1), Figure 1, B) followed by a quite fast decay until very small currents at $\mathrm{E}<-2.4 \mathrm{~V}$. Progressive decrease of electron exchange efficiency can be seen through the voltammetry at different scan rates, which suggests the formation of a thick poorly conductive layer of $\left\{\mathrm{Ag}-\mathrm{CO}_{2}-\mathrm{M}\right\}$. Now, resting thus modified electrode under the flow of argon (at $0 \mathrm{~V}$ ) permits replacing $\mathrm{CO}_{2}$ with $\mathrm{Ar}$ in the cell atmosphere and in the solution. Surprisingly, the response of the gold electrode indicates that it still reacts with some residual $\mathrm{CO}_{2}$ (Figure 1, C, step (I) slightly shifted relative to the initial step (I), Figure 1, B). It suggests that even under Ar atmosphere, gold still contains quite appreciable amounts of $\mathrm{CO}_{2}$ probably stockpiled in the metal matrix. The observed potential shift of step (I) could be due to the $\mathrm{TMA}^{+}$diffusion inside the metal matrix.

\subsection{Evidence for electrochemically driven insertion/desorption of $\mathrm{CO}_{2}$.}

At smooth gold, the solution $\mathrm{CO}_{2} / \mathrm{DMF} / \mathrm{TMA}^{+}$does not show any oxidation step up to +2.0 V. Gold electrode, preliminarily carboxylated between $-1.1 \mathrm{~V}$ and $-1.9 \mathrm{~V}$ under conditions of Figure 1D (e.g., three consecutive scans, leading to the cathodic insertion of $\mathrm{CO}_{2}$, correspond to $4.5 \times 10^{-7} \mathrm{~mol} \mathrm{~cm}^{-2}$ ), shows quite different response: large irreversible step (II) at $\mathrm{E}_{\mathrm{p}}=+1.76 \mathrm{~V}$. A neat pre-peak is tentatively assigned to the oxidation of the superficial carboxylated layer. Current integration of peak (II)-attributable to the emission of $\mathrm{CO}_{2}$ through the anodic scission of $\mathrm{Au}-\mathrm{CO}_{2}$ bond-suggests that the initial content of $\mathrm{CO}_{2}$ in the multilayer amounts to $4.0 \times 10^{-7} \mathrm{~mol} \mathrm{~cm}^{-2}$. This value is astonishingly close to that obtained during total cathodic charge (leading to complete passivation of the electrode) at the level of step (I). Several experiments matching charge/discharge processes revealed a rather good parity between cathodic and anodic coulometric values. Furthermore, anodic discharge permits to check the emission of $\mathrm{CO}_{2}$ by the gold electrode: see curve 2 (red), Figure 1D; an additional charge-on the condition of weak diffusion of released $\mathrm{CO}_{2}$-allows observing a new current increase of peak $(\mathbf{I})$. Similarly, discharge of a carboxylated gold plate $\left(\approx 1 \mathrm{~cm}^{2}\right)$ near a smooth gold electrode permits demonstrating the local evolvement of carbon dioxide under the conditions of formation of step (I).

\subsection{Some additional remarks on the charge of gold with $\mathrm{CO}_{2}$.}


A SEM image (Figure 2) of Au interface after reduction (Step (I)) unravels superficial change of the pristine gold sample. In our sense, the morphology of the surface looks compatible with insertion of $\mathrm{CO}_{2}$ (formation of $\left\{\mathrm{Au}-\mathrm{CO}_{2}{ }^{-}, \mathrm{M}^{+}\right\}$phase) followed by desorption with large flat deposits. EDS (B) and FTIR (C) confirm surface carboxylation, remaining after sonication. Some traces of fluorine revealed by EDS are thought to arise from the co-insertion of some amount of $\mathrm{BF}_{4}^{-}$anion that is partly involved in the interface structure for compensating the charge of inserted $\mathrm{TMA}^{+}$cations left without a counter charge when the carboxylated interface partly decomposes and entrapped $\mathrm{CO}_{2}$ partly leaves the modified zone.

Finally, Nyquist plots (D) indicate a large increase of the interface impedance.

\subsection{What about glassy carbon covered with a thin gold layer?}

Cathodic behavior of smooth gold in the presence of $\mathrm{CO}_{2}$ was compared to that of a GC-Au electrode (see Figure 2, E and F). Curve E shows four scans almost limited to the step (I). On the anodic branch (1a) we note, as expected, an anodic peak that corresponds to the evolution of $\mathrm{CO}_{2}$ along with a reversible pre-peak specifically assignable to surface decarboxylation. Contrariwise, in F (GC-Au electrode), the insertion (first scan) occurs in two consecutive steps assigned to the insertion into gold with following carboxylation of GC [8]. Quite amazingly, these two processes merge from the second scan to a single step located between them, which could correspond to the insertion into an intimately mixed material $\{\mathrm{GC}$ + Metal $\}$. Now the emission of $\mathrm{CO}_{2}$ occurs according to a sole huge peak $\left(4 \times 10^{-7} \mathrm{~mol} \mathrm{~cm}^{-2}\right)$ clearly shifted toward less anodic potentials. Therefore, it is expected that dual solid materials used for the insertion of $\mathrm{CO}_{2}$ may possess peculiar properties. This behavior is confirmed with several mixed metals and alloys (Cu-Pd and Ag-Pd).

\section{Conclusion}

The insertion of $\mathrm{CO}_{2}$ into gold and $\mathrm{GC}-\mathrm{Au}$ electrodes under described conditions is apparently limited to small-size electrolyte cations: $\mathrm{TMA}^{+}$and $\mathrm{Na}^{+}$. The process occurring at about $-1.4 \mathrm{~V}$ vs. $\mathrm{Ag} / \mathrm{AgCl}$ is apparently of catalytic nature due to gold. The present contribution reveals a fundamental difference of insertion of $\mathrm{CO}_{2}$ into gold compared to the process with silver [18], due to the oxidation of $\mathrm{Ag}^{+}$in the over-process. Preliminary experiments suggest the carboxylation of metal surface to occur through the inclusion of $\{\mathrm{Au}-$ $\left.\mathrm{CO}_{2}^{-}, \mathrm{TMA}^{+}\right\}$layers whose thickness progressively increases with the amount of electricity injected in this process. The cathodic insertion was found to be related to anodic release of $\mathrm{CO}_{2}$ (around $+1.8 \mathrm{~V}$ ). The whole process thus corresponds to a simple reversible 
insertion/emission of $\mathrm{CO}_{2}$ into gold and it certainly deserves to be considered for other metals as well as for numerous applications at the micrometric scale.

\section{Figure captions}

\section{Figure 1}

(A) Response of an Au electrode in DMF/0.1 $\mathrm{M} \mathrm{Bu}_{4} \mathrm{NBF}_{4}$ : (1)-baseline, (2)-saturated solution of $\mathrm{CO}_{2}$; (3)-saturated solution of $\mathrm{CO}_{2}$ in $\mathrm{DMF}^{-} 0.1 \mathrm{M} \mathrm{TMABF}_{4}$. (B) Progressive decay of cathodic current of saturated solution of $\mathrm{CO}_{2}\left(\mathrm{~T} \cong 20^{\circ} \mathrm{C}\right)$ in $\mathrm{DMF} / 0.1 \mathrm{M} \mathrm{TMABF}_{4}$ at a smooth $\mathrm{Au}\left(0.8 \mathrm{~mm}^{2}\right)$ during consecutive scans up to its quasi disappearance. $v=100 \mathrm{mV} \mathrm{s}^{-1}$. (C) Response of $\mathrm{Au}$ electrode charged with $\mathrm{CO}_{2}$ after replacing $\mathrm{CO}_{2}$ with Ar in the electrochemical cell (in DMF / 0.1 M TMABF 4 ). (D) Cathodic charge $\left(50 \mathrm{mV} \mathrm{s}^{-1}\right)$ and progressive carboxylation of $\mathrm{Au}$ electrode under $\mathrm{CO}_{2}$ atmosphere (decay of step I after several cathodic scans), followed by 2 anodic scans (vertex potential $1.9 \mathrm{~V}$ ). Total decarboxylation of $\mathrm{Au}$ is seen in second anodic scan (red) through the total disappearance of II (oxidation of organometallic phase $\left.\left\{\mathrm{Au}-\mathrm{CO}_{2}{ }^{-}, \mathrm{TMA}^{+}\right\}\right)$. Afterwards, another cathodic scan (2), marked in red, shows the beginning of a new carboxylation process (whose signal is quasi overlapping with the initial carboxylation process).

\section{Figure 2}

Carboxylation of gold. (A) SEM of $\left\{\mathrm{Au}-\mathrm{CO}_{2}^{-}, \mathrm{TMA}^{+}\right\}$interface, (B) EDS elemental composition, (C) FTIR, A: $v_{\mathrm{OH}}, v_{\mathrm{CH}}, 3200-2600 \mathrm{~cm}^{-1}$; B: $v_{\mathrm{C}=\mathrm{O}}, 1700-1600 \mathrm{~cm}^{-1}$; C: $\delta_{\mathrm{C}-\mathrm{O}}, \delta_{\mathrm{CH}}$, 1440-1230 $\mathrm{cm}^{-1}$; D: $\delta_{\mathrm{OH}}, 930 \mathrm{~cm}^{-1}$. (D) Nyquist plot (reduction of tetracyanobenzene, $3 \mathrm{mM}$ ): (a) at $\mathrm{Au}-\mathrm{CO}_{2}^{-}, \mathrm{TMA}^{+}$, (b) at same interface, after anodic discharge of $\mathrm{CO}_{2}$, (c) after mechanical removal of the modified layer. (E) Charge/discharge processes of gold between $1.5 \mathrm{~V}$ and $+2.0 \mathrm{~V}$ under $\mathrm{CO}_{2}$ atmosphere $\left(\mathrm{DMF}+\mathrm{TMAClO}_{4}\right)$. Total amounts of electricity within the cathodic (charge) and the anodic $\left(\mathrm{CO}_{2}\right.$ evolution) ranges are equal. (F) Use of a $\mathrm{GC}$ electrode electrolytically covered with a thin deposit of gold $\left(6 \times 10^{-4} \mathrm{~mol} \mathrm{~cm}^{-2}\right)$. Charge and discharge of the dual electrode by voltammetry (solution of $\mathrm{CO}_{2}$ in $\mathrm{DMF}+\mathrm{TMAClO}_{4}$ ). The charge-huge oxidation peak II-accumulated in the layer is fairly high: $4 \times 10^{-7} \mathrm{~mol} \mathrm{~cm}^{-2}$ (corresponding to almost $0.1 \mathrm{~mm}^{3}$ of $\mathrm{CO}_{2}$ ).

\section{Scheme 1}

Electrochemical carboxylation-decarboxylation of gold in the presence of $\mathrm{TMA}^{+}$cations 


\section{References}

[1] F. I. Podvorica, In: Aryl diazonium salts, Ed. M. Chehimi, Wiley-VCH Verlag \& Co, Weinheim (2012) 255.

[2] V. Jouikov, J. Simonet, Electrochem. Commun., 56 (2015) 20.

[3] L. Horner, H. Neumann, Chem. Ber. 98 (1965) 1715.

[4] P. Hapiot, J. Simonet, Electroanal. Chem., 23 (2010) 105.

[5] E. Kariv-Miller, P.B. Lawin, J. Electroanal. Chem. 247 (1988) 345.

[6] E. Kariv-Miller, P. D. Christian, V. Svetlicic, Langmuir, 11 (1995) 1817.

[7] G.C. Bond, C. Louis, D. T. Thompson, Catalysis on Gold, Imperial College Press, 2006, and references cited.

[8] M. Frasconi, A. D’Annibale, C. Favero, F. Mazzei, A. M. Santucci, J. Am. Chem. Soc;, 112 (1990) 4301.

[9] J. Lehr, B. E. Williamson, B. S. Flavel and A. Downard, Langmuir, 25 (2009) 13503.

[10] H. Gehan, L. Fillaud, N. Felidj, J. Aubard, P. Lang, M. M. Chehimi and C. Mangeney, Langmuir, 26 (2010) 3975.

[11] J. Simonet, Electrochem. Commun., 21 (2012) 22.

[12] V. Jouikov, J. Simonet, Electrochem. Commun., 45 (2014) 32.

[13] V. Jouikov, J. Simonet, Electrochem. Commun., 43 (2014) 67.

[14] C. Amatore, J.-M. Savéant, J. Am. Chem. Soc., 103 (1981) 5021.

[15] B.R. Eggins, C. Ennis, R. McConnell, M. Spence, J. Appl. Electrochem., 27 (1997) 706.

[16] M. Jitaru, J. Univ. Chem. Technol. Metallurgy 42 (2007) 333.

[17] M. Jödecke, A. P. S. Kamps, G. Maurer, J. Chem. Eng. Data, 57 (2012) 1249.

[18] J. Simonet, Electrochem. Commun., 58 (2015) 11. 


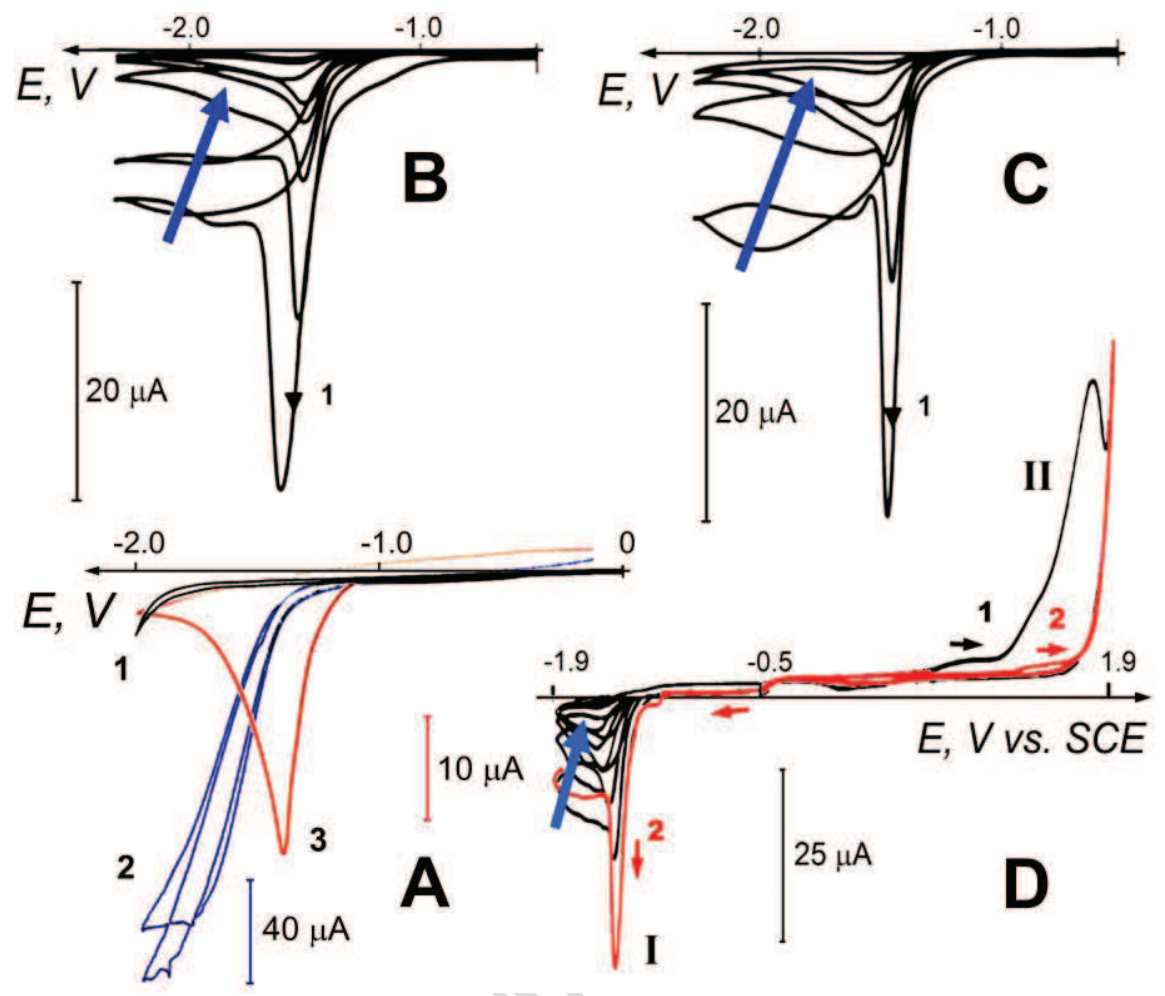

Figure 1
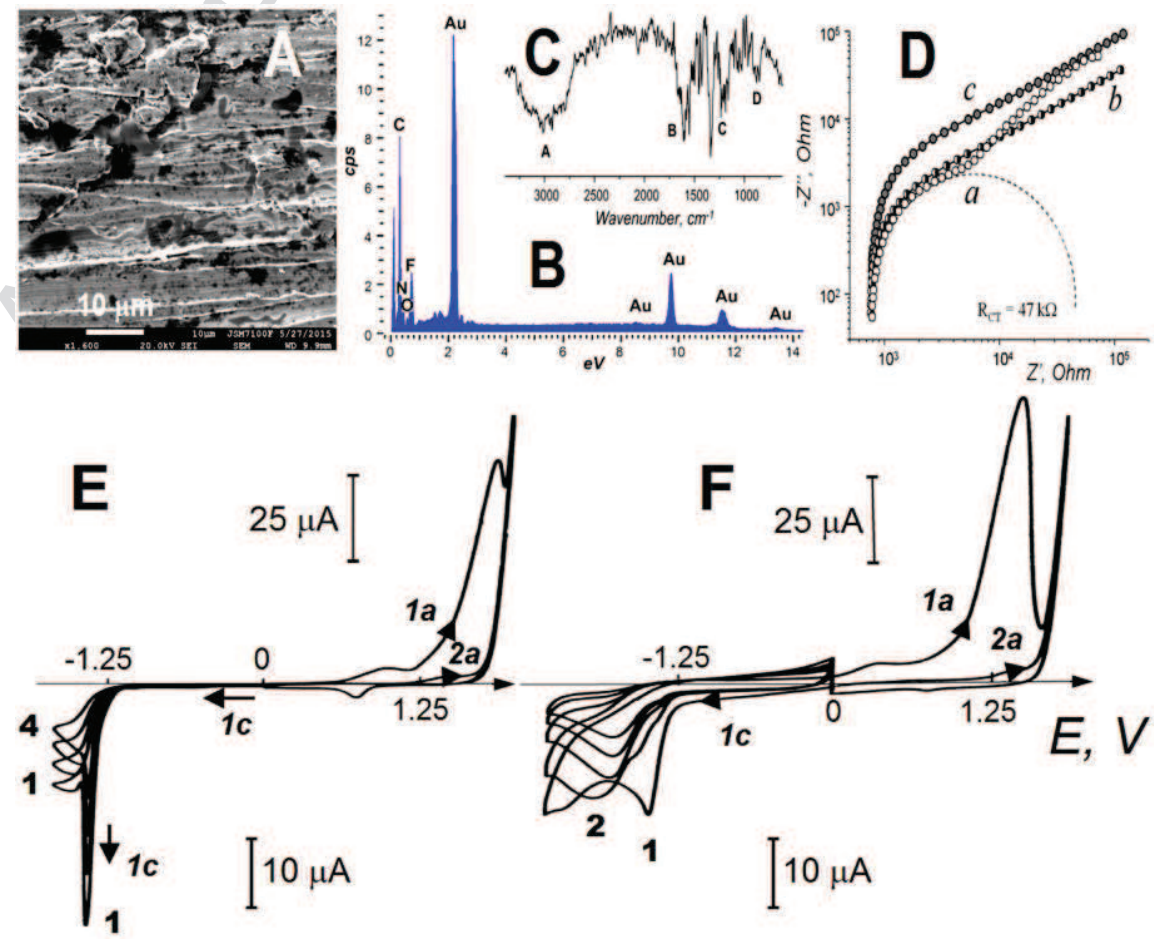

Figure 2 


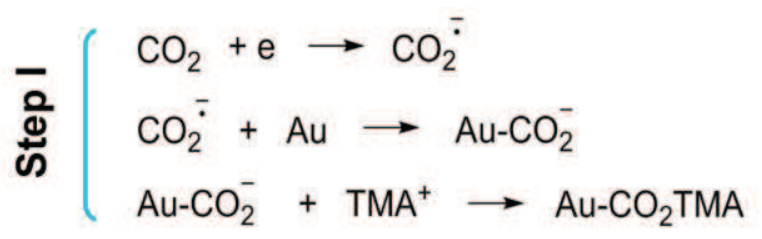

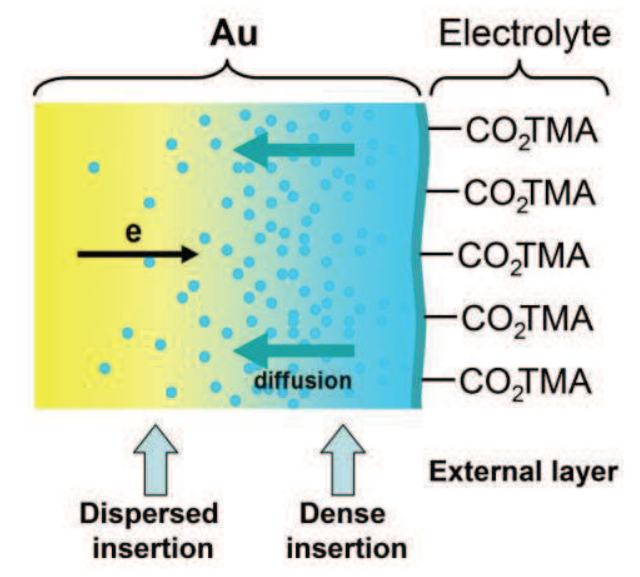

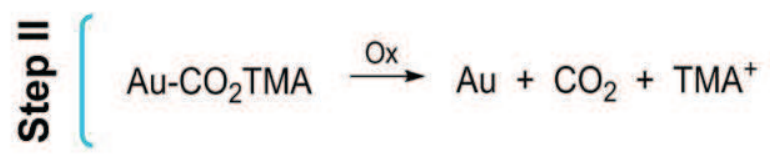

Scheme 1 


\section{Highlights}

Insertion/desorption of carbon dioxide in gold by cathodic means $>$ Releasing of $\mathrm{CO}_{2}$ inserted by electrochemical pulse $>$ New 3D modification of gold $>$ A novel process applicable to small size electro-active molecules $>$ A nanometric sequestration of $\mathrm{CO}_{2}$ in gold $>$ Surfacial carboxylation of gold. 